\title{
How to help the choice of waterproof insulation to be sustainable?
}

\author{
Grzegorz Ginda \\ Faculty of Management, AGH University of Science and Technology, Cracow, Poland \\ E-mail: gginda@zarz.agh.edu.pl
}

\begin{abstract}
Buildings serve different purposes which are denoted as functions. Function of buildings is ensured by the application of adequate structural and formal means. Contemporary buildings are of complex nature, therefore, and consist of diverse components which play specific roles. Besides, some of them are crucial for a specific structural, functional or formal purpose while other play rather secondary role. Insulation is one of the most important building components. This is because it is accountable for proper protection of structural building components against negative influences of external and internal climate conditions. It also provides necessary means for occupational safety and comfortable building exploitation. Waterproof insulation belongs to one of the most accountable building components. It is mainly applied for the protection of a building interior against water inflow from the surrounding atmospheric and underground environment. It nevertheless can be also applied for different reasons e.g. for protecting partitions in wet compartments against getting wet. Diversity of waterproof insulation application purposes results in a considerable number of technical and technological insulation solutions. Such diversity makes the choice of the proper waterproof insulation a hard task. Moreover, the implementation of circular economy idea makes insulation choice even a more difficult problem. This is why the application of specialised approaches for supporting decision with this regard is welcome. A proposal for such approach is presented in the paper. The approach may benefit from the application of different decision support tools. A specific implementation of the approach is finally discussed. The implementation makes effective use of some renowned decision support tools. The comprehesive and universal nature of the proposed approach makes it also suitable for other specific purposes e.g. reliable bid selection.
\end{abstract}

Keywords: sustainable materials and their production, decision support systems in construction, operational research, maintenance and renovation of buildings.

\section{Introduction}

Contemporary buildings comprise complex technical systems. The systems are made up by lower level systems (subsystems). The subsystems are responsible for satisfying functional, structural and formal needs and requirements of diverse stakeholders. The needs and requirements deal with sound building life cycle implementation. This is why the stakeholders are involved in different stages of a general building lifecycle. The stages include design, construction planning, actual construction, exploitation, and final utilization after use. The stakeholders are interested in both internal system issues as well as the interactions between a building and surrounding environment.

Subsystem of building insulation playscritical role for building use. This is because even slight malfunction of the subsystem may lead to considerable consequences in building usage comfortand even to exclusion of a building or its parts from normal exploitation (Chłądzyński \& Gawron, 2016; Kaliszuk-Wietecka, 2017). Waterproof insulation of roofs and substructure are particularly fragile in this regard.

Two dimensions are commonly considered while evaluating the suitability of available waterproof insulation options, namely technical dimension and economical dimension (Zabielski, Szafranko, \& Bogacz, 2017). The use (or possible misuse) of waterproof insulation may nevertheless result in other consequences too. The consequences deal with technological, social, environmental and other issues. Reliable waterproof insulation choice represents, therefore, a kind of sustainable choice problem. Moreover, life cycle of a waterproof insulation covers diverse stages, namely: construction, use and utilization after total wear, at least. Some organisational and technological issues and diversity of perspective stakeholders make the choice problem even more complex (Becker et al., 2018; Wiens, 2014). This is why there is an urgent need for providing adequate means for acomprehensive assessessment of suitability of possible waterproof insulation alternatives to be able to recommend a really sustainalble one. An approach which provides necessary means for the recommendation of a sustainable waterproof insulation alternative is presented, therefore, in the paper. 
The remaining part of the paper is structured as follows. The second section is devoted to diverse flavours of waterproof insulation technology and issues which deal with their life cycle. Detailed issues which pertain to the elaboration of final waterproof insulation recommendation are discussed in the third section. The proposed procedure for recommending a sustainable technology alternative is also presented there. The last section is devoted to final conclusions.

\section{Building waterproof insulation}

Insulation subsystem provides means for ensuring appropriate conditions for comfortable building use. The components of the subsystem are mainly responsible for the protection of building interiors against adverse atmospheric conditions, noise, fire and inflow of external media like underground water or water vapour into a building. This is why the ensuring leakproofness and continuity of the insulation is required. Waterproof insulation is generally responsible for not allowing water and water vapour to penetrate building envelope and to access building interiors. Waterproof insulation is customised to deal with one of three special cases. The cases are devoted to the protection against penetration of:

1. Underground water under pressure.

2. Water resulting from rainfall, snow and ice melting or normal use of wet compartments e.g. bathrooms as well as underground water not under pressure.

3. Water vapour.

A heavy waterproof insulation is applied to protect building interiors in the first case. It is utilised in building substructure. A semi-heavy (medium) waterporoof insulation is utilised in the second case. It is mainly applied in roofs, balconies and terraces as well as wet compartment wall structures. A light waterproof insulation provides necessary means for the protection of a building substructure when underground water level is under building foundations.

Specific tasks of waterproof insulation result in the differences in material applied for a waterproof insulation and waterproof insulation structure. For example, heavy waterproof insulation consists of multiple material layers or a single thick layer while a single thin material layer may be enough in the case of a light waterproof insulation.

There are diverse material options available with regard to waterproof insulation (Klemm, 2008):

- elastic waterproof products e.g. plastic and rubber foils and building papers,

- building paper shingles,

- waterproof sealing compounds,

- metal sheets,

- ceramic and concrete roofing-tiles,

- bituminous, plastic, fibre-cement and other plates,

- putties and similar sealing compounds,

- small-size components e.g. roof slate plates etc.

The advancement in building technology laso resulted in several waterproof structural materials (Bastert, Fingerloos, \& Kiltz, 2018; Zhang, 2011).

Note that presented waterproof options are devoted to specific kinds of tasks and are available in different flavours. Let's use a building paper as an example. It is generally applied as a basic roof cover as well as an auxiliary water vapour proof layer. This is why both top cover building paper and bed layer building paper are offered in building market. To obtain desired properties available building papers are based on the application of different materials. For example, cardboard, glass veil, glass fabric, unwoven fabric, aluminium strip, glass veil-glass fabric combination, pure polyester fabric or polyester fabric with glass fibres may be utilised to form a warp for a building paper. Building paper may be applied in different ways which result from particular needs connected to a kind of a bed they are laid on as well as actual weather and organisational conditions in a building site. Asphalteous roofing pitch, welding, self-sticking, and mechanical fixing are available in this regard. The aforementioned material testifies for the fact that rich assortments of even such a simple waterproof material as building paper covers a wide application range. On the other hand, however, thismakesthe choice of appropriate building paper option a rather cumbersome task while trying to satisfy detailed needs. Similar remarks may also apply to thee choice of other waterproof options as well.

Let's characterise the application areas of the remainingwaterproof options now. Elastic waterproof products are good candidates for a mere application in roof covering as well as waterproof and water vapour proof insulations. Building paper shingles, ceramic and concrete tiles are well suited to steep roofscovering. Bituminous waterproof sealing components may be applied both in a cold and in a hot manner to create coating which is capable of protecting both horizontal and vertical building partitions. Metal sheets are made from copper,aluminium and corrosion-resistant steel. They are well suited for creating self-supporting insulation on a continuous bed. Self-supporting structures are also provided by the application of waterproof structural materials. For example, waterproof concrete (Bastert et al., 2018) is usually applied to createa watertight building substructureand a roof deck construction. 
Aforementioned material shows that the suitability of a given waterproof insulation option always depends not only on its inherent features but also on actual conditions of its application. Each choice of appropriate option thus deals with a uniqueand specific situation. One should not forget that each waterproof insulation alternative available has to satisfy official technical standards to be officially offered on a building market. This is why the importance of other - mainly non-technical factors which describe actual choice situation rises considerably.

\section{Comprehensive assessment of waterproof insulation alternatives}

\section{Survey of actual insulation application conditions}

A comprehensice and exhaustive assessment is required to develop a reliable recommendation of appropriate waterproof insulation alternative. Some issues have to be addressed in this tegard. At first, specific conditions which deal with actual decision making situation should be determined. Possible opportunities and threads as well as clear advantages and disadvantages resulting from the application of any waterproof insulation in actual conditions ought to be considered. All life cycle stages should be included. Utilisation of opinions of diverse stakeholders is also welcome. Thus, teamwork techniques may also prove useful in this regard.

\section{Identification of the most meaningful attributes and the key requirements}

Information about actual conditions makes reliable indentification of the most important waterproof insulation attributes for each life cycle stage possible. The attributes provide necessary means for presumptive and reasonable description of candidate waterproof insulation alternatives. Note that a set of meaningful attributes usually consist of both tangible (quantitative) and intangible (qualitative) attributes. The application of both kinds of the attributes provide necessary means for a reliable and comprehensive assessment of water proof alternative quality. Note that it is a good idea to exclude cost attributes from actual decision analysis of considered waterproof insulation alternatives to leave it for final discrimination of alternatives. This is because costs have a readable discriminant power.

The identification of the most important waterproof insulation attributes allows to formulate key requirements that each possible waterproof insulation alternative should meet. The key requirements facilitate effective discrmination of possible waterproof insulation alternatives. Only waterproof insulation alternatives which meet key requirements may be promoted for becoming prospective candidate alternatives. Note that in the case of the attributes which are addressed in technical standards use of requirements for a higher waterproof product class or even rising standard requirements may help in more effective discrimination of numerous waterproof insulation alternatives.

\section{Final determination of prospective alternatives and attributes}

Construction market offers diverse and numerous products. Possible considerable number of prospective alternatives may significantly inhibit their assessment. The application of discriminant analysis may help in this regard. However, direct application of discriminantanalysis may be also hindered by the huge number of possible alternatives. It nevertheless seems that this problem may be mitigated by a multi-stage discriminant analysis application. The initial step of discriminant analysis of such a kind would deal with distinct general classes of waterproof insulation alternatives. The following steps would consider class components at different levels. One must be nevertheless aware that the actual application of such proposal would require the aggregation of data to describe classes of waterproof insulation alternatives and their subclasses in a comprehensive and reliable way.

The identification of prospective waterproof insulation alternatives delivers necessary means for actual decision analysis. Efficient decision making analysis neverthless requires that neither number of decision making alternatives nor number of attributes exceeds limits of cognitive abilities of a man (Miller, 1956). So, excessive number of decision making alternatives and attributes which describe them need to be limited. Cluster analysis seems to be capable of providing necessary means for the effective limitation of the number of waterproof insulation alternatives to representative ones. Other possible approach to obtain a small set of representative waterproof insulation alternatives deals with repeating the discriminant analysis for different sets of affine alternatives. Note that the effects of a discrimination analysis may also gain advantage from the application of particular contexts e.g. a way of actual implementation of insulation or basement preparation needs.

The excessive number oftangible attributes may be mitigated by the application of well known statistical technique of correlation analysis while other tools e.g. a renowned magic quadrant-like importance-performance analysis IPA (Azzopardi \& Nash, 2013) may be applied to limit excessive number of intangible attributes.

\section{Final recommendation of waterproof insulation}

\section{Decision analysis}

There are plenty of decision analysis techniques available. However, the application of both tangible and intangible attributes for descripton of waterproof insulation alternatives limits a set of suitable decision analysis techniques. Since difference in the assessments of alternatives compared in a pair-wise manner is a difference, no matter 
how the actual assessments are expressed, it seems that the use of Pareto efficiency and dominance concepts may help in this regard. This is because both aforementioned concepts exploit only differences in assessments of alternatives. The application of the concepts offers a meaningful advantage. The advantage results from a comprehensive expression of alterrnative dominance by means of a dominance structure use. Dominance structure has also mathematical representation provided by dominance (di)graph. Since the digraph may be expressed by matrices, the application of dominance structure facilitates possible automation of analysis.

Sample dominance structures are illustrated in Figure 1. Digraph nodes illustrate alternatives 'a'-' $h$ ' while digraph arcs express dominance direction. The leftmost dominance digraph expresses hierarchical dominance structure. There is a clear dominance of two alternatives, namely ' $a$ ' and ' $b$ '. Note that ' $\mathrm{f}$ ' alternatve neither dominate any other alternative nor is dominated by any other alternative. In such the case the cheapest alternative from three aforementioned alternatives would be recommended. However, if non-dominated alternatives would become unavailable for some reasons (e.g. the excessive costs) then adjacent dominance hierarchy level alternatives, namely 'e', 'g' and ' $h$ ' would be considered for the recommendation. Of course, if even them were unavailable then the recommendation of alternative 'c' would be considered, and so on. On the other hand, the rightmost dominance structure illustrates the case when there is no dominating alternative at all. The application of decision support tools would beneeded to recommend final choice in such the case. The use of ranking tools seems appropriate. However, the presence of both tangible and intangible attributes in description of considered alternatives suggests the application of two different kinds of approaches - one for tangible attributes and the other one for the intangible attributes. The renowned VIKOR (Opricovic \& Tzeng 2007) technique seems natural choice for tangible attributes. This is because it offers reasonable discriminating capabilities. Any available intangibility-aware technique e.g. AHP/ANP (Saaty, 1996) or a related technique may be applied in the case of intangible attributes. Final recommendation of waterproof alternative(s) results then from the comparison of outcomes of the application of techniques of both kinds. In the case of unclear outcomes cost attributes would be applied to elaborate final recommendation for waterproof insulation.
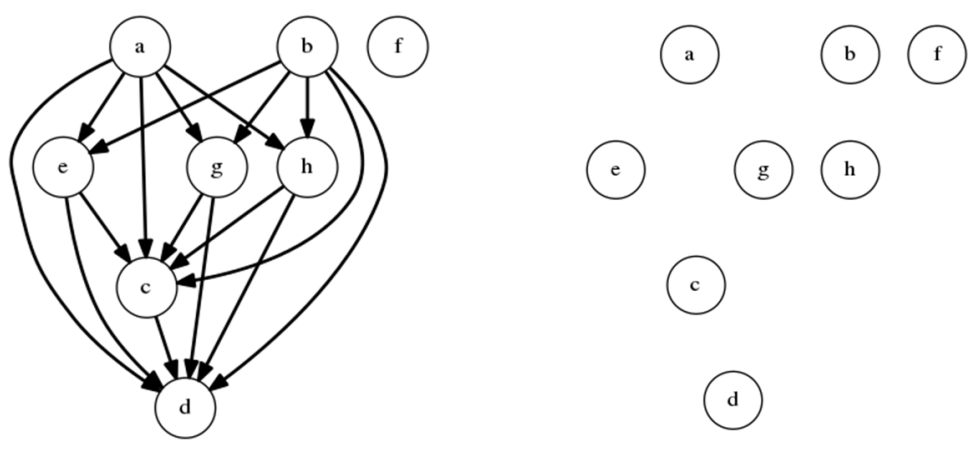

Figure 1. Dominance digraphs for considered alternatives (source: own work)

Note that the influence of different total cost components may be considered during the elaboration of final recommendation. This is why a need for additional - cost-related analysis may occur. Costs nevertheless comprise tangible attributes. The application of VIKOR would also do, therefore, while making final recommendation in such the case.

\section{Proposed procedure}

Aforementioned discussion makes it possible to present the procedure that elaborates final recommendation for a waterproof insulation. The procedure consists of following steps:

1. Determination of actual conditions for use of a waterproof insulationfor a whole life cycle.

2. Presumptive choice of meaningful attributes for a whole life cycle of a waterproof insulation beside costs.

3. Determination of requirements for possible waterproof insulation for all meaningful attributes beside costs.

4. Introductory choice of prospective candidate alternatives for whole life cycle based on the requirements.

5. Identification of the key attributes amongst meaningful attributes.

6. Identification of representative candidate alternatives for whole life cycle.

7. Global discrimination of representative candidate alternatives (and presumptive global ranking of representative candidate alternatives).

8. Final recommendation of the best alternative(s) based on global discrimination results (or a presumptive global ranking) and cost attributes.

Components of the procedure arecomprehensively presented in Table 1. 
Table 1. Proposed procedure components (source: own work)

\begin{tabular}{|c|l|l|l|l|}
\hline Stage & \multicolumn{1}{|c|}{ Action } & \multicolumn{1}{|c|}{ Stakeholders } & \multicolumn{1}{c|}{ Tools } & Results \\
\hline 1 & $\begin{array}{l}\text { Actual conditions determina- } \\
\text { tion }\end{array}$ & $\begin{array}{l}\text { Whole life cycle } \\
\text { stakeholders }\end{array}$ & Teamwork support tools & Actual conditions \\
\hline 2 & $\begin{array}{l}\text { Presumptive choice of } \\
\text { meaningful attributes }\end{array}$ & $\begin{array}{l}\text { Whole life cycle } \\
\text { stakeholders }\end{array}$ & Teamwork support tools & $\begin{array}{l}\text { Set of meaningful } \\
\text { non-cost attributes }\end{array}$ \\
\hline 4 & $\begin{array}{l}\text { Detrmination of requirements } \\
\text { spective candidate alterna- } \\
\text { tives }\end{array}$ & $\begin{array}{l}\text { Whole lofe cycle } \\
\text { stakeholders } \\
\text { engineering experts } \\
\text { etc. }\end{array}$ & $\begin{array}{l}\text { Teamwork support tools } \\
\text { tise, discriminant analysis }\end{array}$ & $\begin{array}{l}\text { Set of meaningful at- } \\
\text { tribute-related require- } \\
\text { ments }\end{array}$ \\
\hline 5 & $\begin{array}{l}\text { Identification of the key } \\
\text { attributes }\end{array}$ & Analyst & $\begin{array}{l}\text { Statistical analysis, magic } \\
\text { alternatives } \\
\text { quadrant-like IPA analysis etc. }\end{array}$ & $\begin{array}{l}\text { Reduced set of the } \\
\text { non-cost attributes }\end{array}$ \\
\hline 6 & $\begin{array}{l}\text { Identification of the repre- } \\
\text { sentative alterrnatives }\end{array}$ & Analyst & $\begin{array}{l}\text { Cluster analysis, discriminant } \\
\text { analysis etc. }\end{array}$ & $\begin{array}{l}\text { Set of representative } \\
\text { candidate alternatives }\end{array}$ \\
\hline 7 & $\begin{array}{l}\text { Global discrimination of } \\
\text { representative alternatives }\end{array}$ & Analyst & $\begin{array}{l}\text { Dominance analysis (with pos- } \\
\text { sible support of ranking tech- } \\
\text { niques: VIKOR, AHP/ANP } \\
\text { etc.) }\end{array}$ & $\begin{array}{l}\text { Dominance structure } \\
\text { (and possible ranking) } \\
\text { of representative alter- } \\
\text { natives }\end{array}$ \\
\hline 8 & Final recommendation & $\begin{array}{l}\text { Analyst, decision } \\
\text { maker }\end{array}$ & $\begin{array}{l}\text { The application of cost attrib- } \\
\text { utes }\end{array}$ & $\begin{array}{l}\text { Choice of the best rep- } \\
\text { resentative alternative }\end{array}$ \\
\hline
\end{tabular}

\section{Conclusions}

A procedure is proposed in the paper to recommend a sustainable waterproof insulation alternative. The procedure is capable of considering whole life cycle of waterproof insulationand the multiplicity of possible alternatives as well as the needs corresponding with actual application conditions and vaste interests of diverse stakeholders. The influence of both tangible and intangible attributes iseasily addressed by the procedure thanks to the application of a concept of Pareto efficiency-based dominance and specialised decision analysis techniques. The procedure also considers cognitive limits of a man while preparing final recommendation.

The application of procedure comprises vital enhancement for common economic-technical analysis of possible waterproof insulation options. It thus provides useful means for optimising the choice of waterproof insulation. However, the reality of the application of waterproof insulation (Chłądzyński \& Gawron, 2016; Kaliszuk-Wietecka, 2017) shows that the proposed approach may prove to be especially useful in the case of reliable, durable, economically efficient and generally sustainable choice of replacement for the existing faulty waterproof insulations.

The procedure is flexible enough to allow gaining advantage thanks to the application of further enhancements. For example, the use of non-determinant data e.g. interval data would also help in enriching the analysis and making it more suited to use available imperfect information. A kind of sensitivity analysis might be also introduced to enhance the analysis e.g. by means of simultaneous application of multiple decision support tools. On the other hand, universal framework of the procedure makes it a suitable candidate for supporting decisions which deal both with with the recommendation of other building industry products, too. The proposed approach seems also suitable for the case of building tenders. This is because it is capable of promoting transparent decisions which aren't biased by any suspicion of dishonesty.

\section{Acknowledgements}

The work was financed by a subsidy for scientific research provided by AGH UST, Cracow, Poland.

\section{References}

Azzopardi, E., \& Nash, R. (2013). A critical evaluation of importance-performance analysis. Tourism Management, 35, $222-233$. https://doi.org/10.1016/j.tourman.2012.07.007

Bastert, H., Fingerloos, F., \& Kiltz, D. (2018). Bedarfsplanung und Grundlagenermittlung für WU-Betonbauwerke [Brief for building design for waterproof concrete structures]. Beton- und Stahlbetonbau Spezial, 113(S1), 52-60. https://doi.org/10.1002/best.201750002

Becker, H.-R., Filusch, S., Frisch, J., Hohmann, R., Horstmann, M., Kiltz, D., Krell, J., Krause, J., \& Zitzelsberger, T. (2018). Wasserundurchlässige Bauwerke aus Beton: Empfehlungen für die Zusammenarbeit von Bauherr, Planer, Fachplaner und 
Ausführenden [Waterproof concrete constructions - Recommendations for the cooperation of client, planner, special planner and contractor]. Beton- und Stahlbetonbau, 113(S1), 67-73. https://doi.org/10.1002/best.201700095

Chłądzyński, S., \& Gawron, M. (2016). Dlaczego systemy hydroizolacji tarasów i balkonów nie są skuteczne? [Why is waterproof insultation ineffective in the case of terraces and balconies?]. Materiaty budowlane, 10, 53-54.

Kaliszuk-Wietecka, A. (2017). Poprawne zaprojektowanie i wykonanie izolacji wodochronnych - wiedza a rzeczywistość [Proper waterproof insulation design and implementation - knowledge vs. reality]. Materiaty budowlane, 3, 2-3. https://doi.org/10.15199/33.2017.03.01

Klemm, P. (Ed.). (2008). Budownictwo ogólne [General civil engineering]. Fizyka budowli (vol. 2) [Building thermal analysis]. Arkady, Warsaw.

Miller, G.A. (1956). The magical number seven, plus or minus two some limits on our capacity for processing information. Psychological Review, 63(2), 81-97. https://doi.org/10.1037/h0043158

Opricovic, S., \& Tzeng, G.-H. (2007). The Compromise solution by MCDM methods: A comparative analysis of VIKOR and TOPSIS. European Journal of Operational Research, 156(2), 445-455. https://doi.org/10.1016/S0377-2217(03)00020-1

Saaty, T. L. (1996). Decision making with dependence and feedback: The analytic network process. RWS, Pittsburgh.

Wiens, U. (2014). Wasserundurchlässige Bauwerke aus Beton - Erfolg nur im Team! [Structures made of concrete impermeable to water - Success only in the team!]. Beton- und Stahlbetonbau, 109(S1), 1-1. https://doi.org/10.1002/best.201490102

Zabielski, J., Szafranko, E., \& Bogacz, P. (2017). Wybrane rozwiązanie materiałowe pionowych izolacji wodochronnych [Selected material solutions of vertical waterproof insulation]. Materialy budowlane, 10, 60-61. https://doi.org/10.15199/33.2017.10.20

Zhang, J. (2011). New waterproof insulation roof building materials and the construction. Advanced Materials Research, 261-263, 633-637. https://doi.org/10.4028/www.scientific.net/AMR.261-263.633 